\title{
Comparative Analysis of Competition Power in High Technology and Low Technology Intensive Manufactures
}

\author{
${ }^{1}$ Metin Yildirim, ${ }^{2}$ Ferda Nakipoğlu Özsoy \\ ${ }^{3}$ Asst. Prof. Aslı Özpolat, ${ }^{4}$ Dr. Filiz Çayirağasi \\ ${ }^{1}$ Asst. Prof, Faculty of Economics \& Administrative Sciences/Economics, University of \\ Necmettin Erbakan, Turkey \\ ${ }^{2}$ Asst. Prof, Faculty of Economics \& Administrative Sciences/Economics, University of \\ Gaziantep, Turkey \\ 3,4 Oguzeli Vocational School of Higher Education, University of Gaziantep, Turkey
}

\begin{abstract}
An increase in competition power provides more profitability by affecting the amount of production and export. By the increase in technology, innovation and R\&D investments in recent ages in the world, high technology industries became even more important for competitive power. In this study, two analyses covering the data from 1995 to 2015 have been considered. In the first analysis, the competitiveness of the high-tech and low-tech sectors has been compared by using RCA index for selected countries. In the second analysis, the relationship between competition power and growth, total factor productivity and R\&D expenditures have been analyzed by using GMM.
\end{abstract}

Keywords: Competitive power, High technology-intensive manufactures, Low technologyintensive manufactures, RCA, GMM, Total factor productivity, Research and development expenditure

\section{Introduction}

There are two sources of economic growth: the first is the increase in the stock of production factors, and the other is the technological development. Although production factors such as labour and capital are increasing, technology is also advancing rapidly. Data for industrial production are categorised into four levels of technological development: high technology and low technology. Two technology groups are identified at the bottom of R\&D intensity of economic activities such as R\&D expenditure on value added (Jaegers et.al, 2013).

High technology includes the most advanced technology available and the latest technology. High-tech products not only new but also previously unconsidered products-offer technological solutions to customers' problems (Atmer and Thagesson, 2005:31). High-tech commodities are extremely diverse regarding their qualities and usability. Grouped by technological complexity at varying degrees, high-tech commodity companies need to utilise other basic skills and key competencies when designing, manufacturing and selling. They also cater to varied customers according to their purchasing and use conditions. The markets for high-tech products are the most dynamic emerging markets in the world, and their growth is mainly based on the development of information and technology (Wiechoczek, 2016:80-81). The high-tech category comprises the production of chemicals, general and specific aim machines, motor devices, computing machines, pharmacological products and electronic equipment (Liu and Daly, 2011:17). 


\section{Metin Yildirim, Ferda Nakipoğlu Özsoy, Aslı Özpolat, Filiz Çayiră̆asi \\ Comparative Analysis of Competition Power in High Technology and Low Technology Intensive Manufactures}

Low-tech, traditional companies, are at the heart of the established system, which can be invested in through well-recognized market channels. Low-tech companies incur fewer costs for R\&D, but their fixed costs are higher than those in the high technology sector because although their product features require a minimum level of technology development, they require more expensive raw materials compared to those of the high-tech sector (Atmer and Thagesson, 2005:32). Low technology category contains production of leather and related products, food, rubber, plastic, wearing apparel, wooden, sheet and sheet product, furniture, printing and recording, refined petroleum, beverages, tobacco textiles coke and coke (Liu and Daly, 2011:17).

In the literature, many studies have shown that the biggest increase in real income per capita in industrialized countries is due to technological improvement. Know-how in technologically condensed activities is more important for economic growth. It is, therefore, each country should specialise in exports of high-tech goods.

High-tech exports contain all products with high investigation and development condensed, like medical products, computing machines, software, scholarly materials, electronic and other electrical equipment and components (Gani, 2009:31). Expertness in these high-tech goods is used to catch technology consistency of exports (Srholec, 2005:1). High-tech industries are major sources of employment growth, profit, and innovation in both products and processes (Kask and Sieber, 2002:16). Connolly (2003) emphasised the significance of imports in the transmission of technology. It is notably greater for developing countries than for advanced countries because third world countries are not very integrated with advanced nations. Furthermore, high-tech imports from advanced countries have a favourable impact on interior innovation and imitation. In addition, it has caused an increase in GDP growth by higher quality monetary fund goods are used in interior production. Gani (2009) has noted that to provide a strong witness of the favorable impact of high-tech exports on per capita growth in countries with higher degrees of technological progress.

The advance of the industry sector raises productivity, and the growth of the manufacturing industry can be possible only through export, which is why Kaldor (1968) considered the manufacturing industry to be growth's engine. Kaldor's Growth Laws are four laws relating to the causation of economic growth. First, an increase in the growth rate in the manufacturing sector brings about an increase in the growth rate in GDP. Second, the increased growth rate in manufacturing output causes an increase in the growth rate in labour productivity in the manufacturing sector, which causes increasing returns to scale. Third, demand in the agricultural sector determines the growth of manufacturing output in the early steps of development and exports in the later steps. Fourth, the increased growth rate in exports and output causes economic growth in the long term (Blecker, 2009, pp. 4-5).

According to Lucas (1988), countries can be grouped into two categories. The first group of countries produces high-tech goods, whereas the second group of countries focuses on lowtech goods. Lucas emphasized that the ratio between the human capital rate and substitutability rate of high-tech goods is statistically significant and higher than that of lowtech goods. The effect of the export of high-tech goods on growth will be more significant than the effect of the export of low-tech goods. Therefore, Lucas claimed that countries should specialize in exporting high-tech goods.

Chakrabarti (1991) emphasized that technology is a keystone in competitiveness. Technological development and growth play crucial roles in determining the competitiveness of the world marketplace. Cuaresma and Wörz (2005) are tested the effect of exports with distinct technologic context on economic growth for 45 developed and developing countries over the period 1981 to 1997 . According to the result of the study, high-tech exports show the better performance than domestic sectors because of productivity differential for only 
developing countries. The effect of exports has a significant difference on growth based on the technology consistency. Advantages of high-tech exports exceed the advantages of low-tech exports.

Cuneo and Mairesse (1984) examined the relationship between productivity and R\&D for 182 firms between 1972 and 1977. The result of the study showed that the elasticity of R\&Dperforming firms is twice that of other firms. Griliches and Mairesse (1984) supported the results found by Cuneo and Mairesse. Harhoff's (1998) and Tsai and Wang's (2004) studies showed that the R\&D elasticities of high-tech firms differ from those of other firms by analyzing different countries' firms within different periods. According to the results of the studies, the R\&D elasticity of the high-tech sector is highest. As regards to the result of Verspagen's (1995) study of 15 manufacturing sectors in nine OECD countries, R\&D has a positive and important impact on productivity in high-tech industries. Kafourous (2005) found similar results for UK manufacturing sectors. An R\&D investment has a positive effect on high-tech sectors but no impact on low-tech sectors.

Because of the reasons above, the dynamic relationship between Competition Power, Total Factor Productivity, Growth, and Research and Development R\&D expenditure has been analyzed in this study. In this scope, two models were used to compare differences between low-tech- and high-tech- intensive sectors. The models have been estimated using yearly data from 1995 to 2015 for 16 selected countries. To compare the differences between and the impact of the variables, the analysis has been constituted into two stages. At the first stage of the analysis, the competition power was calculated by us according to the revealed comparative advantage (RCA) method. At the second stage of the analysis, we used the generalised method of moments (GMM). In the models, competition powers, which we calculated according to the RCA method, are the dependent variables. The other variables are GDP, R\&D expenditure, and total factor productivity (TFP).

\section{Data and Empirical Analysis}

The data included in the study cover the 1995-2015 annual series of the selected 15 OECD (Turkey, India, Korea, Japan, China, Germany, Belgium, Poland, Hungary, France, Austria, UK, Israel, Finland and Canada) countries. The relationship between high-tech export competitiveness and low-tech export competitiveness, growth rate, and productivity has been tested through the GMM. Within this scope, two different models have been created. Whereas the dependent variable in the first model is the high-technology exports' competitive power index, the second model is the low-technology exports' Competitive Power Index. In both models, the independent variables have been determined as National Income (GDP in 2005 U.S. dollars), R\&D Expenditures, and TFP. We calculated the competition power indices, which are dependent variables, according to the RCA method. We derived the GDP and R\&D from the World Bank and the TFP, which is used as a productivity indicator, from the Conference Board Total Economy Database. We used logarithmic variables in the study. Model 1 is expressed as:

(1)

HRCA: High Technology Competition Power Index

GDP: Gross Domestic Product

TFP: Total Factor Productivity

RD: Research and Development Expenditure

Model 2 is as follows:

(2)

LRCA: Low Technology Competition Power Index

GDP: Gross Domestic Product

TFP: Total Factor Productivity

RD: Research and Development Expenditure 
Metin Yildirim, Ferda Nakipoğlu Özsoy, Aslı Özpolat, Filiz Çayiră̆asi

Comparative Analysis of Competition Power in High Technology and Low Technology Intensive Manufactures

We used two steps to analyse the relationship between competition power, growth rate, R\&D expenditure, and TFP. For the first step, we calculated the RCA index according to BelaBalassa. With this index, during the second step of the analysis, the relationship between the competition powers of high-technology- and low-technology-intensive sectors and GDP, TFP, and R\&D was analysed using the generalised method of moments.

\subsection{RCA Analysis}

The RCA approach was developed and used by Balassa (1965). In this approach, countries are examined to determine the relative export performance of certain products. Developed by Balassa, this index is formulated as follows:

$$
\mathrm{RCAij}=(\mathrm{Xij} / \mathrm{Xit}) /(\mathrm{Xwj} / \mathrm{Xwt})
$$

Where Xij determines the exports goods $j$ of country $i$, Xit is total exports of country $i, X w j$ is goods $j$ exports of other countries, and Xwt determines the total exports of other countries. If the value of the index is more than one, it means that the country has a superiority in the field; if it is small, it means that the country lacks competitiveness in the production of that good. However, if the value of the index is less than one, the country has less competitiveness in the production of that product than others in the field. An index value of more than one means that the country has the advantage of the area covered, and

$\mathrm{RCA}<1 \Rightarrow$ the competitiveness of the country in $\mathrm{j}$ good has a comparative disadvantage;

$\mathrm{RCA}>1 \Rightarrow$ competitiveness of the country in j good has comparative advantage;

$\mathrm{RCA}=0 \Rightarrow$ country does not have $\mathrm{j}$ good exports.

Figure 1 shows the high-tech competition power (HRCA) and low-tech competition power (LRCA) indices for the countries selected between 1995 and 2015.

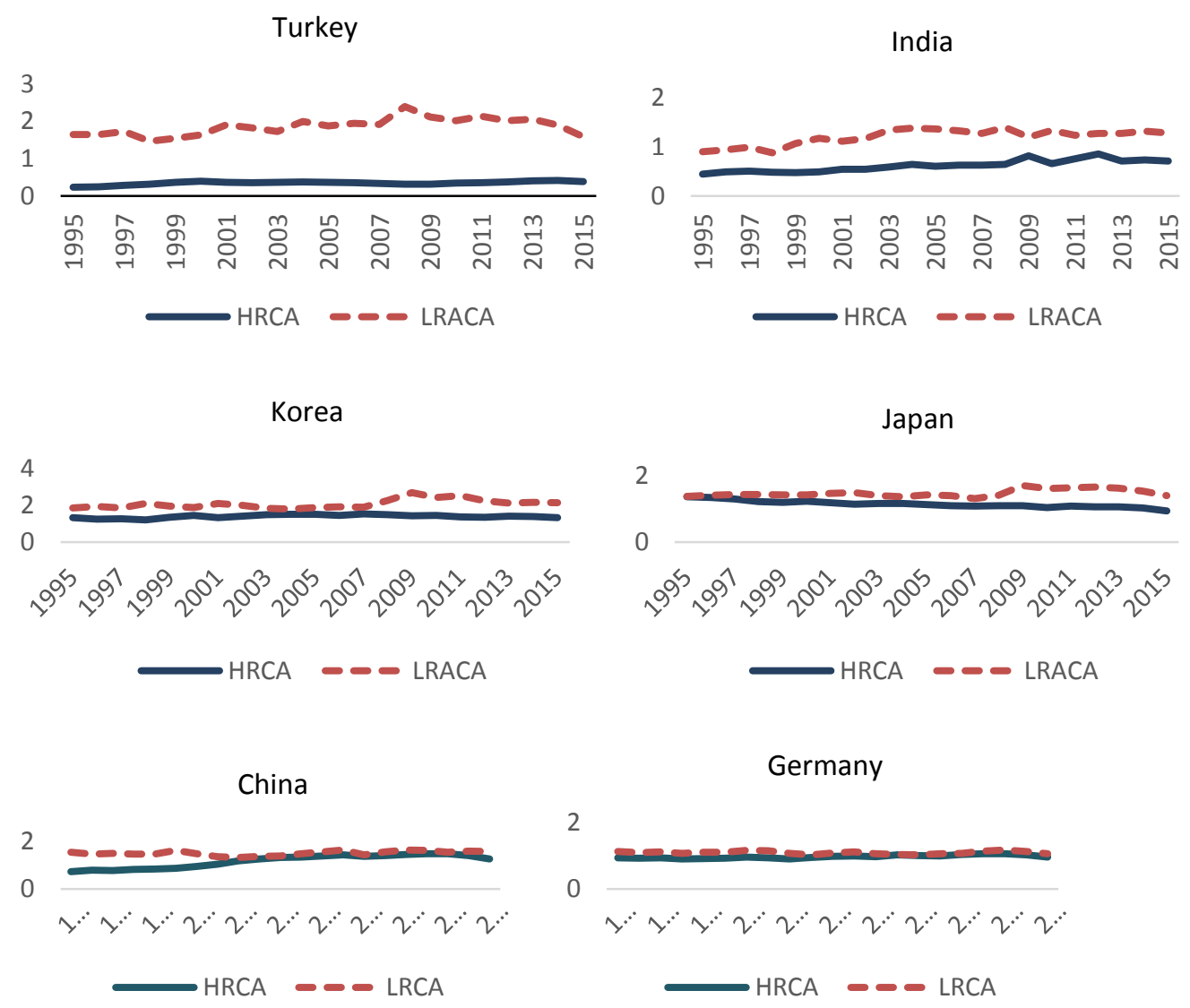

Figure 1: Competition Power Index for Selected Countries 
Metin Yildirim, Ferda Nakipoğlu Özsoy, Aslı Özpolat, Filiz Çayirağasi

Comparative Analysis of Competition Power in High Technology and Low Technology Intensive Manufactures

The countries that hold the most important advantages in high-tech sectors are Japan, Korea, China, and Germany. These countries have a comparative advantage over other countries in both high- and low-technology sectors. Although Turkey and India, which are developing countries, concentrate on low technology, Korea seems to have a significant advantage against Turkey and India in both sectors. Although the export power of Japan declined over time in both areas, the powers of China, Germany, India, and Korea increased relative to all the countries evaluated. In Turkey, the competition power of high technology increased at a low rate over the period, whereas the competitiveness of the country's low-technology exports has increased, except the last two years. According to this result, Korea and Japan have more competition power in high-tech sectors than Turkey and India do. Among the countries, Turkey has the least competition power. Turkey's RCA index was 0.22 in 1995; in 2015, its RCA index was 0.38 . Therefore, Turkey has no comparative advantage in the high-tech sector. However, in Germany and Japan, the RCA indexes were as follows, respectively: in 1995, 0.935 and 1.36 and 2015, 0.955 and 0.932. Even though each country's RCA index decreased in 2015, some countries still had comparative advantages against the other countries.

Table 1 also shows the results of the competition index of the other selected countries included in the analysis. Poland, Austria, and Finland have competitive advantages in lowtechnology-intensive sectors, whereas Israel and the United Kingdom have high competitiveness in high-technology-intensive sectors; Belgium, France, and Hungary have significant advantages in both sectors. As the level of human capital and technology of the firms has increased, the firms' competitiveness powers have also increased. The Israeli economy is based on the production of high-tech equipment, agriculture, industry, diamond processing, and tourism; Israel is a major player in the high-tech industry. For this reason, Israel's high-tech industry is a major growth engine. The United Kingdom is considered high tech in relation to other countries. The heart of the high-tech zone, known as "Silicon Fen," is in the United Kingdom, which is why the United Kingdom has an important advantage in high-tech sectors.

Table 1: Result of RCA Index for Countries

\begin{tabular}{|l|l|l|}
\hline & & Poland \\
\hline Year & Lrca & Hrca \\
\hline 1995 & 2.250844448 & 0.403374808 \\
\hline 1996 & 2.330123237 & 0.434572109 \\
\hline 1997 & 1.862278607 & 0.467317777 \\
\hline 1998 & 2.200165914 & 0.425432452 \\
\hline 1999 & 2.194431963 & 0.382292041 \\
\hline 2000 & 2.251564624 & 0.416603447 \\
\hline 2001 & 2.489939035 & 0.410535259 \\
\hline 2002 & 2.444693078 & 0.419876708 \\
\hline 2003 & 2.264793265 & 0.430107643 \\
\hline 2004 & 2.070259276 & 0.413076422 \\
\hline 2005 & 1.844000485 & 0.433577041 \\
\hline 2006 & 1.767419566 & 0.489146548 \\
\hline 2007 & 1.729177632 & 0.53667222 \\
\hline 2008 & 1.662185737 & 0.642722398 \\
\hline 2009 & 1.512219603 & 0.67626436 \\
\hline 2010 & 1.458598312 & 0.733965458 \\
\hline 2011 & 1.669798406 & 0.696803851 \\
\hline 2012 & 1.703397856 & 0.70792466 \\
\hline 2013 & 1.795145061 & 0.708326583 \\
\hline
\end{tabular}


Metin Yildirim, Ferda Nakipoğlu Özsoy, Aslı Özpolat, Filiz Çayiră̆asi Comparative Analysis of Competition Power in High Technology and Low Technology Intensive Manufactures

\begin{tabular}{|c|c|c|}
\hline 2014 & 1.708670067 & 0.712417328 \\
\hline \multirow{2}{*}{2015} & 1.638105019 & 0.680439838 \\
\hline & & Hungary \\
\hline Year & Lrca & Hrca \\
\hline 1995 & 1.021420682 & 0.642965825 \\
\hline 1996 & 1.137607535 & 0.565277791 \\
\hline 1997 & 0.801962043 & 0.864734121 \\
\hline 1998 & 0.749890503 & 0.888821473 \\
\hline 1999 & 0.760476708 & 0.940189117 \\
\hline 2000 & 0.757222422 & 1.077176923 \\
\hline 2001 & 0.757195349 & 0.997454011 \\
\hline 2002 & 0.70367339 & 1.045874773 \\
\hline 2003 & 0.676975087 & 1.128112141 \\
\hline 2004 & 0.67520022 & 1.261439949 \\
\hline 2005 & 0.658748883 & 1.206308154 \\
\hline 2006 & 0.656990817 & 1.185276205 \\
\hline 2007 & 0.616572706 & 1.172467278 \\
\hline 2008 & 0.620599038 & 1.2694737 \\
\hline 2009 & 0.542620833 & 1.317282096 \\
\hline 2010 & 0.57334939 & 1.341514748 \\
\hline 2011 & 0.634068084 & 1.315312323 \\
\hline 2012 & 0.683854618 & 1.178801542 \\
\hline 2013 & 0.756762724 & 1.105508551 \\
\hline 2014 & 0.736774431 & 0.974481958 \\
\hline \multirow[t]{2}{*}{2015} & 0.696859861 & 0.867695151 \\
\hline & & France \\
\hline Year & Lrca & Hrca \\
\hline 1995 & 1.071126925 & 1.047172472 \\
\hline 1996 & 1.111028652 & 1.124724217 \\
\hline 1997 & 1.065445759 & 1.074780195 \\
\hline 1998 & 1.031658316 & 1.057673483 \\
\hline 1999 & 1.067304369 & 1.052098314 \\
\hline 2000 & 1.167190711 & 1.109935119 \\
\hline 2001 & 1.131749479 & 1.113137289 \\
\hline 2002 & 1.112366754 & 1.075378347 \\
\hline 2003 & 1.139888454 & 1.056295317 \\
\hline 2004 & 1.045147139 & 1.060815321 \\
\hline 2005 & 1.08837461 & 1.095909367 \\
\hline 2006 & 1.10405806 & 1.131578212 \\
\hline 2007 & 1.111521778 & 1.136880002 \\
\hline 2008 & 1.059632698 & 1.227132873 \\
\hline 2009 & 1.051136083 & 1.227794654 \\
\hline 2010 & 1.05523464 & 1.28138081 \\
\hline 2011 & 0.986209435 & 1.329856686 \\
\hline 2012 & 1.009075279 & 1.374841146 \\
\hline 2013 & 1.045198612 & 1.389279384 \\
\hline 2014 & 0.996141326 & 1.351849755 \\
\hline \multirow[t]{2}{*}{2015} & 1.133366316 & 1.428608329 \\
\hline & & Austria \\
\hline
\end{tabular}


Metin Yildirim, Ferda Nakipoğlu Özsoy, Aslı Özpolat, Filiz Çayiră̆asi Comparative Analysis of Competition Power in High Technology and Low Technology Intensive Manufactures

\begin{tabular}{|c|c|c|}
\hline Year & Lrca & Hrca \\
\hline 1995 & 1.734643493 & 0.547156715 \\
\hline 1996 & 1.68873337 & 0.548737718 \\
\hline 1997 & 1.660657639 & 0.608019213 \\
\hline 1998 & 1.792896715 & 0.58896959 \\
\hline 1999 & 1.761062361 & 0.584214398 \\
\hline 2000 & 1.707435372 & 0.598993776 \\
\hline 2001 & 1.673206028 & 0.605648224 \\
\hline 2002 & 1.645760201 & 0.635449421 \\
\hline 2003 & 1.75727681 & 0.654677833 \\
\hline 2004 & 1.630562462 & 0.663133129 \\
\hline 2005 & 1.687766865 & 0.627404848 \\
\hline 2006 & 1.701254712 & 0.645004273 \\
\hline 2007 & 1.756770635 & 0.674418464 \\
\hline 2008 & 1.776987207 & 0.704286811 \\
\hline 2009 & 1.776045271 & 0.720239035 \\
\hline 2010 & 1.803764662 & 0.729091061 \\
\hline 2011 & 1.879978901 & 0.754687196 \\
\hline 2012 & 1.945980386 & 0.785139464 \\
\hline 2013 & 2.055410148 & 0.817002615 \\
\hline 2014 & 2.048318542 & 0.804251199 \\
\hline \multirow[t]{2}{*}{2015} & 1.948489476 & 0.736182996 \\
\hline & & UK \\
\hline Year & Lrca & $\mathrm{Hrca}$ \\
\hline 1995 & 0.860963355 & 1.396870297 \\
\hline 1996 & 0.865232957 & 1.38493557 \\
\hline 1997 & 0.860102475 & 1.334624034 \\
\hline 1998 & 0.791125389 & 1.336494631 \\
\hline 1999 & 0.787647567 & 1.302096875 \\
\hline 2000 & 0.743549235 & 1.179183328 \\
\hline 2001 & 0.743689598 & 1.247395631 \\
\hline 2002 & 0.723637375 & 1.251113148 \\
\hline 2003 & 0.772051187 & 1.180282272 \\
\hline 2004 & 0.796150841 & 1.125689939 \\
\hline 2005 & 0.80099943 & 1.201062754 \\
\hline 2006 & 0.739455506 & 1.380022564 \\
\hline 2007 & 0.834015917 & 1.085239738 \\
\hline 2008 & 0.777237255 & 1.098516079 \\
\hline 2009 & 0.736407994 & 1.024267921 \\
\hline 2010 & 0.702356408 & 1.092592883 \\
\hline 2011 & 0.640265927 & 1.02707827 \\
\hline 2012 & 0.671307933 & 1.067524085 \\
\hline 2013 & 0.662311696 & 0.898411995 \\
\hline 2014 & 0.734668912 & 1.09563909 \\
\hline \multirow[t]{2}{*}{2015} & 0.651235827 & 1.121043751 \\
\hline & & Israel \\
\hline Year & Lrca & Hrca \\
\hline 1995 & 0.443223545 & 1.272787716 \\
\hline
\end{tabular}


Metin Yildirim, Ferda Nakipoğlu Özsoy, Aslı Özpolat, Filiz Çayiră̆asi Comparative Analysis of Competition Power in High Technology and Low Technology Intensive Manufactures

\begin{tabular}{|c|c|c|}
\hline 1996 & 0.503480477 & 1.335449993 \\
\hline 1997 & 0.518557312 & 1.38531785 \\
\hline 1998 & 0.508697648 & 1.397415717 \\
\hline 1999 & 0.482125361 & 1.36626767 \\
\hline 2000 & 0.505981939 & 1.045594052 \\
\hline 2001 & 0.505665301 & 1.061192136 \\
\hline 2002 & 0.422561531 & 0.971485718 \\
\hline 2003 & 0.405471213 & 1.034012203 \\
\hline 2004 & 0.387042157 & 1.024854429 \\
\hline 2005 & 0.445736058 & 0.972472728 \\
\hline 2006 & 0.498893726 & 1.046834673 \\
\hline 2007 & 0.4258455 & 0.897668675 \\
\hline 2008 & 0.512520014 & 1.636094294 \\
\hline 2009 & 0.443768182 & 1.801373487 \\
\hline 2010 & 0.435758691 & 1.704484766 \\
\hline 2011 & 0.437007534 & 1.754540525 \\
\hline 2012 & 0.420618371 & 1.77294172 \\
\hline 2013 & 0.404577884 & 1.812899683 \\
\hline 2014 & 0.451043627 & 1.690696262 \\
\hline \multirow[t]{2}{*}{2015} & 0.433963272 & 1.664566934 \\
\hline & & Finland \\
\hline Year & Lrca & Hrca \\
\hline 1995 & 1.499966725 & 0.739713642 \\
\hline 1996 & 1.67853967 & 0.789186482 \\
\hline 1997 & 1.361785299 & 0.857017905 \\
\hline 1998 & 1.328077543 & 0.917730236 \\
\hline 1999 & 1.336050363 & 0.956541742 \\
\hline 2000 & 1.352121547 & 1.052850612 \\
\hline 2001 & 1.569067863 & 0.97488358 \\
\hline 2002 & 1.492698158 & 0.983165189 \\
\hline 2003 & 1.677675306 & 0.980077993 \\
\hline 2004 & 1.614392404 & 0.926280214 \\
\hline 2005 & 1.447673873 & 1.066962892 \\
\hline 2006 & 1.626341395 & 0.948036861 \\
\hline 2007 & 1.641563984 & 0.934197433 \\
\hline 2008 & 1.435029339 & 1.002518604 \\
\hline 2009 & 1.315674648 & 0.77523809 \\
\hline 2010 & 1.764980578 & 0.764125999 \\
\hline 2011 & 1.659364284 & 0.74223262 \\
\hline 2012 & 1.560188283 & 0.718710448 \\
\hline 2013 & 1.610847885 & 0.66188151 \\
\hline 2014 & 1.436423004 & 0.598323853 \\
\hline \multirow[t]{2}{*}{2015} & 1.408025577 & 0.520392364 \\
\hline & & Canada \\
\hline Year & Lrca & $\mathrm{Hrca}$ \\
\hline 1995 & 0.566743835 & 0.5585329 \\
\hline 1996 & 0.624579455 & 0.561906513 \\
\hline 1997 & 0.619560768 & 0.552447796 \\
\hline
\end{tabular}


Metin Yildirim, Ferda Nakipoğlu Özsoy, Aslı Özpolat, Filiz Çayiră̆asi

Comparative Analysis of Competition Power in High Technology and Low Technology Intensive Manufactures

\begin{tabular}{|c|c|c|}
\hline 1998 & 0.663238567 & 0.543034293 \\
\hline 1999 & 0.656410946 & 0.51166225 \\
\hline 2000 & 0.614608713 & 0.574692034 \\
\hline 2001 & 0.586707185 & 0.534719139 \\
\hline 2002 & 0.626107354 & 0.49687346 \\
\hline 2003 & 0.572941386 & 0.504482426 \\
\hline 2004 & 0.551604345 & 0.504642774 \\
\hline 2005 & 0.548503973 & 0.526219125 \\
\hline 2006 & 0.55360959 & 0.548218658 \\
\hline 2007 & 0.526199291 & 0.594221731 \\
\hline 2008 & 0.525611155 & 0.599766688 \\
\hline 2009 & 0.503609608 & 0.630269436 \\
\hline 2010 & 0.510802664 & 0.574725106 \\
\hline 2011 & 0.472021828 & 0.591987006 \\
\hline 2012 & 0.514554257 & 0.560489458 \\
\hline 2013 & 0.500996933 & 0.550422556 \\
\hline 2014 & 0.494765303 & 0.530140015 \\
\hline \multirow[t]{2}{*}{2015} & 0.521867079 & 0.556812569 \\
\hline & & Belgium \\
\hline Year & Lrca & Hrca \\
\hline 1995 & 1.051218922 & 0.792435493 \\
\hline 1996 & 1.018590245 & 0.812730353 \\
\hline 1997 & 1.040229507 & 0.835940696 \\
\hline 1998 & 1.038532963 & 0.842898757 \\
\hline 1999 & 1.055998816 & 0.880376453 \\
\hline 2000 & 1.121916331 & 0.908028161 \\
\hline 2001 & 1.041662488 & 0.948458457 \\
\hline 2002 & 0.976663714 & 1.080634886 \\
\hline 2003 & 0.976484599 & 1.125653238 \\
\hline 2004 & 1.026233683 & 1.12966232 \\
\hline 2005 & 1.0724858 & 1.175573823 \\
\hline 2006 & 1.118845083 & 1.166531693 \\
\hline 2007 & 1.156301462 & 1.227027406 \\
\hline 2008 & 1.138862175 & 1.270958871 \\
\hline 2009 & 1.007883675 & 1.3181679 \\
\hline 2010 & 1.01495363 & 1.304634266 \\
\hline 2011 & 1.057924659 & 1.297872858 \\
\hline 2012 & 1.016295179 & 1.303254975 \\
\hline 2013 & 0.991533481 & 1.279903828 \\
\hline 2014 & 1.018760751 & 1.250573071 \\
\hline 2015 & 1.009703638 & 1.213333761 \\
\hline
\end{tabular}

\subsection{GMM Analysis}

In the second phase of the study, the generated models will be analysed by the GMM. The OLS estimator and the GLS estimator sometimes produce deviations in estimates of dynamic panel data sets; for this reason, Arrellano and Bond (1991) developed a more effective method: the GMM. In this method, dynamic panel data analyses use the past period value of the dependent variable as the instrumental variable, taking the differences of the variables in the first order (Baltagi, 2001:130-131). 
Arrellano and Bond's (1991) GMM is either one staged or two staged. In the one-stage model, the error is not serially correlated and has homoscedastic features. Descriptive variables are not correlated. The one-stage model is expressed as follows:

$$
\begin{aligned}
& \hat{\delta}_{1}=\left[\left(\Delta y_{-1}\right){ }^{\prime} W\left(W^{\prime}\left(I_{N} \times G\right) W\right)^{-1} W^{\prime}\left(\Delta y_{-1}\right)\right]^{-1} \\
& x\left[\left(\Delta y_{-1}\right)^{-1} W\left(W^{\prime}\left(I_{N} \times G\right) W\right)^{-1} W^{\prime}(\Delta y)\right]
\end{aligned}
$$

If the error term is heteroscedastic, a two-stage GMM estimator is more appropriate than the one-stage. In the first step of the two-stage estimation, the error terms are assumed to be homoscedastic to time with independent and explanatory variables. The two-stage GMM is formulated as follows:

$$
\hat{\delta}_{2}=\left[\left(\Delta y_{-1}\right)^{\prime} W V_{N} W^{\hat{\prime}}\left(\Delta y_{-1}\right]^{-1}\left[\left(\Delta y_{-1}\right)^{\prime} W V_{N}^{-1} \hat{W}(\Delta y)\right]\right.
$$

This GMM estimator does not require knowledge of the first stage; in other words, its and distributions. GMM analysis is popular because it does not produce problems of autocorrelation and heteroscedasticity. The analysis results obtained within the scope of the study are given in Table 2.

Table 2: Results of Analysis

\begin{tabular}{|l|l|l|}
\hline Variables & Model 1 & Model 2 \\
\hline TFP & $0.00310^{* *}$ & $0.00658^{* *}$ \\
\hline RD & $0.0427 * * *$ & 0.01902 \\
\hline GDP & $0.0056^{* * *}$ & $0.0044 * *$ \\
\hline J-statistics & 12.94046 & 11.28504 \\
\hline J-statistisc Prob. & 0.373383 & 0.504661 \\
\hline
\end{tabular}

$*, * *, * * *$ are refer that probability respectively; $\% 10, \% 5, \% 1$

After obtaining and evaluating the results, we tested the validity of instrumental variables for all models. According to this testing's results, J-statistics implies that the instrumental variables are significant and the null hypothesis is accepted.

According to the results in Model 1 , there is a positive and significant relationship between the competitiveness, productivity, growth rate, and R\&D expenditures of the sectors with advanced technology. Considering the statistically meaningful results, a $1 \%$ increase in TFP increases competitive power by $0.003 \%$. Similarly, a $1 \%$ increase in R\&D and growth create a $0.04 \%$ increase in competition power.

Considering the statistical results of Model 2, there is a positive and significant relationship between the competitiveness, growth, and productivity of low-tech-intensive sectors, but there is no significant relationship between $R \& D$ expenditures and competitiveness. Accordingly, a $1 \%$ increase in TFP brings a $0.006 \%$ increase in competition power and an increase of $1 \%$ in growth leads to a $0.004 \%$ increase in competition power. The level of significance of the variables in Model 1 shows that the relation between high-tech competition power, growth, productivity, and R\&D expenditure is higher than those of the low-tech sectors. Additionally, growth, productivity, and R\&D expenditures impact high-tech competition power more significantly than low-tech competition power. The results of our R\&D expenditure analysis are consistent with the results of the studies of Kafourous (2005), Verspagen (1995), Harhoff (1998), and Tsai and Wang (2004). 
Metin Yildirim, Ferda Nakipoğlu Özsoy, Aslı Özpolat, Filiz Çayirağasi

Comparative Analysis of Competition Power in High Technology and Low Technology Intensive Manufactures

\section{Conclusion}

The purpose of this paper is to investigate the relationship between competition power, GDP Growth Rate, R\&D Expenditure and productivity on low-tech and high tech manufacturing in the OECD countries.

From the analysis, this research concludes findings as below:

1. The data included in the study cover the 1995-2015 annual series of the selected 15 OECD (Turkey, India, Korea, Japan, China, Germany, Belgium, Poland, Hungary, France, Austria, UK, Israeli Finland and Canada) countries.

2. The relationship between high-tech export competitiveness and low-tech export competitiveness, growth rate, and productivity has been tested through the GMM.

3. We calculated the competition power indices, which are dependent variables, according to the RCA method.

4. According to RCA index data calculated of the low-tech- and high-tech-intensive competitiveness of the countries, a competitiveness advantage in the low-technology sector is in Poland, Austria, and Finland, whereas Israel and the United Kingdom have high competitive advantages among the high-tech-intensive sectors. Also, Belgium, France, and Hungary have significant advantages in both sectors.

5. In the second phase of the study, we conducted a GMM analysis. Two different models have been created. Whereas the dependent variable in the first model is the high-technology exports' competitive power index, the second model is the low-technology exports' competitive power index. In both models, the independent variables have been determined as GDP in 2005 U.S. dollars, R\&D expenditures, and TFP.

6. According to the results obtained, the effects of growth, productivity, and R\&D expenditures on a high-tech competition power are positive and significant.

High-tech commodities are various regarding their qualities and usability; high-tech products add great value when compared to other products. These companies, which can be grouped by technological complexity, need to use other basic skills and key competencies when designing, manufacturing and selling their products. High-technology production is directly related to education, research, and innovation; creates positive externality; and increases productivity and human capital quality. Also, their high-tech companies' growth is mainly based on the development of information and technology. Moreover, emphasising these products in the field of exports will also cause countries to have a comparative advantage in the foreign market.

Although the relationship between growth, productivity, and low-tech competition power is positive and meaningful, the relationship between these factors and R\&D expenditures is not significant. Low-tech-intensive sectors are based on established technology. Low-tech companies incur fewer costs for research and development, but their fixed costs are higher than those in the high-technology-intensive sectors because product features require the minimum level of technology development, unlike the high-tech sector.

\section{References}

- Abdul Ahad Riki, Mahendra Putra Kurnia, Erna Susanti, "Tinjauan Hukum terhadap Pelaksanaan PerlindunganHukum Terhadap Tenaga Kerja Harian Lepas (Studi pada CV. Dwijaya Bhakti Rayon Kabupaten Penajam Paser Utara), Jurnal Beraja Niti, ISSN 23374608, volume 3 Nomor 2(2014).

- Agusmidah, 2011, Dilematika Hukum Ketenagakerjaan, Tinjauan Politik Hukum, Jakarta: PT. Sofmedia.

- Christina NM Tobing, "Rekonstruksi Perjanjian Kerja Harian Lepas dalam Hukum Ketenagakerjaan Berbasis Keadilan", Disertasi, Fakultas Hukum Universitas Islam Sultan Agung (Unisula), Semarang, 2016 hlm. 2016. 
Metin Yildirim, Ferda Nakipoğlu Özsoy, Aslı Özpolat, Filiz Çayiră̆asi

Comparative Analysis of Competition Power in High Technology and Low Technology Intensive Manufactures

- Gerry Silaban dan Salomo Perangin-angin, 2008, Hak dan Atau Kewajiban Tenaga Kerja dan Pengusaha/Pengurus yang Ditetapkan Dalam Peraturan Perundangan Keselamatan dan Kesahatan Kerja, Medan: USU Press.

- http://hukum.studentjournal.ub.ac.id/index.php/hukum/article/viewFile/504/4/493 http://ojs.unud.ac.id/index.php/kerthasemaya/article/download/21911/14540

- Imam soepomo,1974, Hukum Perburuhan Bidang Hubungan Kerja, Cet. II, Djembatan, Jakarta.

- Materi Pelatihan Hakim Pengadilan Hubungan Industrial, Kurikulum untuk Hakim Pengadilan Hubungan Industrial, Mahkamah Agung RI dan ILO, Mega Mendung-Bogor, Maret 2013,

- Persen Pekerja Sawit Berstatus Buruh Lepas, dalam:

- https://www.jurnalasia.com/bisnis/agribisnis/70-persen-pekerja-sawit-berstatus-buruhlepas/

- Susi Hadiyati dan Adi Cilik Pierewan, http://www.e-jurnal .com /2016/02/strategibertahan-hidup-buruh-harian.html

- Schclarek, A. (2004). Debt and economic growth in developing and industrial countries. Lund University Department of Economics Working Paper, 2005, 34.

- Stephen N. 2014, Ghana's debt distress threatens economic livelihoods of itscitizens. http://www.ghanaweb.com/GhanaHomePage/features/columnist. 